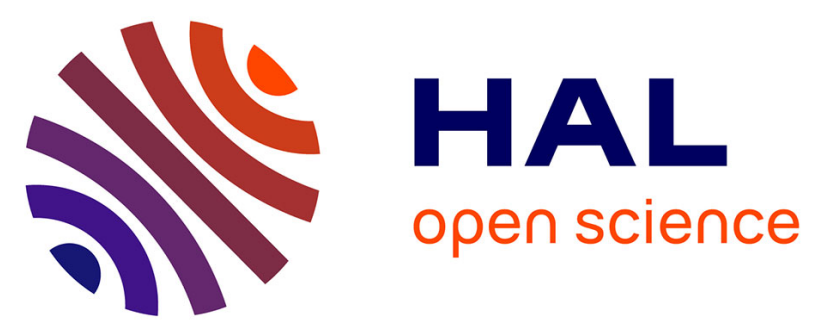

\title{
Fine scale spatialised prospective modelling - a methodological approach. Application to water management in Brittany
}

Thomas Houet, Laurence Hubert-Moy, Cyril Tissot

\section{- To cite this version:}

Thomas Houet, Laurence Hubert-Moy, Cyril Tissot. Fine scale spatialised prospective modelling - a methodological approach. Application to water management in Brittany. Revue Internationale de Géomatique, 2011, 21 (Special Issue 2011), pp.67-93. 10.3166/rig.21hs.67-93 . hal-00617502

\section{HAL Id: hal-00617502 https://hal.science/hal-00617502}

Submitted on 8 Sep 2015

HAL is a multi-disciplinary open access archive for the deposit and dissemination of scientific research documents, whether they are published or not. The documents may come from teaching and research institutions in France or abroad, or from public or private research centers.
L'archive ouverte pluridisciplinaire HAL, est destinée au dépôt et à la diffusion de documents scientifiques de niveau recherche, publiés ou non, émanant des établissements d'enseignement et de recherche français ou étrangers, des laboratoires publics ou privés. 


\title{
Fine scale spatialised prospective modelling - a methodological approach
}

\author{
Application to water management in Brittany
}

\author{
Thomas Houet* ** _ Laurence Hubert-Moy ** _ Cyril Tissot *** \\ * GEODE, UMR 5602 CNRS \\ Université de Toulouse 2 Le Mirail \\ 5, allée A. Machado, F-31058 Toulouse cedex \\ thomas.houet@univ-tlse2.fr \\ ** COSTEL, UMR LETG 6554 CNRS, FR 2116 CAREN \\ Université Rennes 2 Haute Bretagne \\ Place du recteur Henri Le Moal, F-35043 Rennes cedex \\ laurence.hubert@uhb.fr \\ *** GEOMER, UMR LETG 6554 CNRS, FR 2195 IUEM \\ Technopôle Brest Iroise, place Nicolas Copernic, F-29280 Plouzané \\ cyril.tissot@univ-brest.fr
}

RÉSUMÉ. Le principal objectif de ce travail est d'élaborer une démarche méthodologique générique pour réaliser des scénarios prospectifs spatialisés à une échelle locale. Cette démarche, fondée sur la méthode des scénarios en prospective, se nourrit des apports méthodologiques utilisés en modélisation de systèmes complexes. Elle comprend quatre phases : la construction de la "base » des scénarios, l'élaboration des scénarios eux-mêmes, leur spatialisation et leur évaluation. Appliquée au contexte de la gestion de l'eau en Bretagne et plus précisément à la mise en place du SAGE du Blavet, elle est illustrée ici à travers un scénario exploratoire et un scénario normatif visant à évaluer l'impact potentiel de la politique agricole commune de 2006 et de l'agrandissement des exploitations agricoles sur l'évolution à moyen terme des modes d'usages des sols.

ABSTRACT. The main objective of this work is to elaborate a generic methodological approach to build prospective scenarios spatially explicit at a local scale. This approach is based on the scenario method used in prospective studies, and uses methodological techniques developed for the modelling of complex systems. The scenario-development process comprises four steps: construction of the basis, scenario building, giving a spatial dimension to the scenarios, and their evaluation. Applied in the framework of water planning in the Brittany region and more precisely of the application of the Water Planning and Management Schemes (WPMS) on the Blavet watershed, the approach is illustrated here by the example of one explanatory scenario and one normative scenario, both aiming at evaluating the potential impact of the 2006 Common Agricultural Policy and farms enlargement on futures land uses.

MOTS-CLÉS : modélisation, prospective, scénarios, changements d'occupation et d'utilisation des sols, paysages agricoles, analyse spatiale.

KEYWORDS: modelling, prospective, scenarios, land use and land cover changes, agricultural landscapes, spatial analysis. 


\section{Introduction}

\subsection{Issues of land use and land cover changes at a local scale}

Land use and cover changes (LUCC) are a result of anthropogenic (deforestation, urbanisation, intensification etc.) and natural (droughts, cyclones etc.) factors, and the environmental seriousness of its consequences differs. Land use changes influence the circulation and biogeochemistry of the water and the atmosphere, alter the characteristics and functioning of pedological cover and cause variations in biodiversity (Turner et al., 1995). Due to the environmental consequences of these changes, international programmes such as the LAND or GAM (Geographic Analysis and Monitoring Program), (Lambin et al., 1999; Muchoney, 2002), aim to improve knowledge on the nature, scale, causes and consequences of these changes. These programmes essentially relate to major transformations at global or coarse scales. However, it often happens that subtle changes occurring as a result of the intensified use of agricultural land for example, which is not perceived at a global level, go unrecognised or underestimated, even though they may have major environmental consequences on economy and/or health (Hubert-Moy, 2004; UNEP, 2005).

\subsection{The uncertainty about the future of land cover and use}

Future land use changes (over the medium and long term) imply to consider all land development stakeholders. To take decisions in support of sustainable land development, decision-makers often use a prospective approach, a discipline which aims to reduce the uncertainty linked to the future by taking "a look at the future, in order to throw light on current action" (Hatem, 1993).

\subsection{Sustainable water management - an example of the issue of fine scale prospective modelling}

Since the adoption in 2000 of the Water Framework Directive (WFD), water managers have had an obligation of results in restoring the "good ecological condition of natural water bodies and the good potential condition of artificial water bodies which have undergone major changes" by 2015 . The WFD is reflected in French water policy through the establishment of the Water Planning and Management Schemes (WPMS). Their elaboration includes a prospective phase, which allows managers to test different management strategies for large catchment basins taking into account future local specifities of land use, land cover and landscape structures dynamics (hedgerows, riparian wetlands). Indeed, it has been shown that it is at the hedgerow and field levels that bio-geochemical processes characterizing water quality takes place (Cheverry, 1998; Mérot, 1999; Caubel, 
2001; Clément, 2001). Therefore, water quality management is placed within the context of managing agricultural activities and land and requires their possible futures to be clarified at a local scale.

\subsection{Decision support tools for sustainable management at a local scale are still insufficient}

The prospective "scenarios' method" (Godet, 1992) is regularly used in water management studies at the global (Alcamo et al., 1998) or regional (Narcy et al., 2006) level. Few prospective studies have been conducted at a local scale, even though authors (Poux et al., 2001) have shown an interest in working at such a level, particularly to identify management issues and local sources of conflict or even to determine the influence of local factors on the land use changes and farming practices. Moreover, the prospective works are mostly narratives. The advantage of narratives lies in the space of freedom given to readers - mental representations - to become aware of current and future land issues. In parallel, models such as CLUE (Veldkamp and Fresco, 1996) or Environment Explorer (Engelen et al., 2002), have been developed and now provide spatialised simulations of possible land cover futures over medium and long term (20-30 years). However, although they allow a long term vision to be integrated, for the most part, they can be only used at national or regional scales. The narratives or maps produced by models remain insufficient to properly locate precisely critical places for water management in reality. This is all the more true as it has been clearly demonstrated that the spatial organisation of land cover and landscape structures as a result of agricultural activity dynamics (Thenail, 1996; Baudry and Thenail, 2004) has a strong influence on the ecological processes dynamic (Mérot, 1999; Burel et al., 2000; Baudry et al., 2003). Some prospective studies attempted to give a spatial dimension to the resulting prospective scenarios (Flaxman et al., 1996; Steinitz et al., 2003), but on a scale which does not reach the precision of fields or hedgerows.

The objective of this study is to implement a generic methodological framework aiming to produce spatialised prospective scenarios at a local scale. The proposed approach is in the context of water management in France, and specifically in Brittany, where there are major water quality issues. A preliminary definition of the concepts and methods used in prospective and in geography will justify the proposed method, which will then be described. Examples of prospective scenarios and how they are assessed will then illustrate the relevance of the method which will be finally discussed.

\section{Spatialised prospective modelling at a fine scale - state of the art}

This section aims to succinctly present the theoretical references, particularly the conceptual convergences, between prospective and geography, the methodological 
bases of a prospective approach, as well as the methods for integrating the spatial dimension into studies where time is prevalent.

\subsection{Modelling complexity - between a prospective paradigm and a research issue in geography}

Modelling complexity is the prospective paradigm. The construction of a prospective scenario is based on the consideration of all factors (social, economic, geographical etc.) and their interactions within a non-limited space (integration of multiscalar relations) over a previously-defined period. The complexity is the "search for a possibility to think through the complication (i.e. the numerous interretroactions), through the uncertainties and through the contradictions" (Morin, 1990). The complexity paradigm combines unpredictability and forecasting, thus establishing the prospective approach (Piveteau, 1995). In this context, geography possesses all the attributes of complexity - from the simple fact of spatially rendering a complex real world to the integration of natural (biogeographical etc.) and anthropogenic dynamics (agricultural activities, stakeholder activities, etc.) into models and their interactions at different scales influencing landscape changes.

Consideration of all spatial and temporal relations is a common objective to the prospective and the geography disciplines which more generally rely on the analysis of nature/society complex systems. The former aims at better defining the temporal dimension, the latter to better understand and integrate the spatial dimension. The presentation of the methods used in prospective and in geography to model this complexity is the first step in building spatialised prospective scenarios.

\subsection{Prospective scenarios - methodology of construction and typologies}

Scenarios are one of the most widely-used prospective methods. Formally, they consist of coherent narratives describing one or several plausible anticipation(s) of the future, on a given subject (the environment, the economy, social representations etc.) (Poux, 2003).

\subsubsection{The "scenarios' method" in prospective}

While there are different methods of scenario construction, most are based on a common methodology (or "metamethod") which has been synthesised by Godet (1992), and called "the scenarios' method ${ }^{1 "}$. It has two phases - the construction of the "base" and the building of the scenarios.

1. Here we have used Godet's expression (1992) of which some fundamental elements have been appearing since 1977 (Godet, 1977). 
The base can be defined as "the current image of the system, which is as complete, global and explanatory as possible, based on which the prospective study per say (i.e. the scenario-building) can be implemented" (Hatem, 1993). The description of the system must take into account the situation at a time $t$ and its past temporal dynamic. The system is defined by identifying its main variables, which may be both external variables (characterising the system environment) and internal variables (characterising the system stricto sensu). Its analysis must identify the causal relationships between the variables - the driving variables which have a huge influence on the evolution of the system and the "sensitive" variables for which future evolution is the most uncertain. The dynamic of the system is determined during a retrospective analysis which understands past evolution, and identifies stakeholders and variables that have played a role, those that are still involved and those likely to become involved in the future. Once the "base" has been built, it should be possible to define a certain number of "uncertainty dimensions". Hatem (1993) defines an uncertainty dimension as "an uncertainty considered as being decisive for the future of the system (e.g. demographic evolution, a climatic hazard etc.) whose possible realisations will be used as base hypotheses for scenariobuilding". This is done according to the interest of the stakeholders concerned and to the contribution it may bring compared to other scenarios.

The scenarios describe the possible evolution of the system between an initial state and a future defined date, called the temporal horizon. A scenario is based on two rules: (1) the synchronic description of the system at different times of its evolution, called the image; (2) the diachronic description of a succession of hypothetical events and relationships of causality that they maintain with the rest of the system, which constitutes the pathway. Images and pathways can be built using narratives and/or models. Narratives are an "intellectual" and flexible way of dynamically establishing the causal relationships between system variables which bring their coherence to the scenarios (Poux, 2003). Computerised models are more rigid than narratives and have the advantage of providing quantified and/or spatialised data with the help of simulations, which are often more explicit than the qualitative description of narratives. Ultimately, a scenario formally comes under the prospective approach if, and only if, it meets four criteria: relevance, coherence, plausibility and transparency (Godet, 1992).

\subsubsection{Prospective scenarios: typologies}

Exploratory or normative scenarios (also called forecasting and backcasting) differ in their building approaches. The former are based on a known initial situation and progressively explore the future (figure 1a). The latter are based on a desirability standard (desirable or undesirable image) and construct the future up to the present. The pathway is thus built retrospectively (figure1b). They provide more clarification on the risks of breaks and the methods to be implemented in order to meet pre-defined objectives (to avoid a specific situation or to achieve another) while the former illustrate the most plausible trends. 
Trend-based or contrasted scenarios. The former, or "no surprise" scenarios (Hatem, 1993) correspond to a continuation of current trends, without any major breaks, integrating driving forces which are already known and whose probability is certain. Inversely, contrasted scenarios aim to explore break hypotheses, some of which may have a low probability level but which could have a potentially major impact.

Several scenario typologies exist depending on the approach adopted when building the scenario and the level of openness to uncertainty dimensions (Greeuw et al., 2000): "qualitative" (narrative) scenarios versus "quantitative" scenarios (from models); exploratory versus normative scenarios and trend-based versus contrasted scenarios (see box below and figure 1).
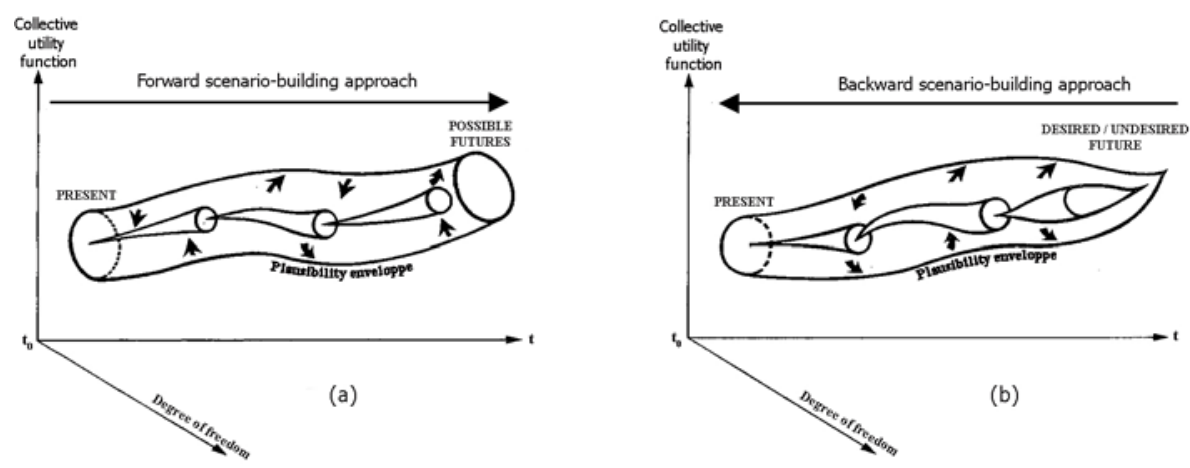

Figure 1. Three-dimensional representation of (a) an exploratory scenario and (b) a normative scenario (from Julien et al., 1975 adapted)

\subsection{Contributions of spatial approaches to spatialised prospective scenario building}

The modelling of land use changes ${ }^{2}$ serves as an excellent example to illustrate the different methods of translating the spatial dimension of complex systems and thus of helping to integrate the spatial dimension within a prospective approach.

\subsubsection{Spatial modelling of land complex systems}

Complexity modelling can be done by following three different approaches: the spatial representation of successive states, the systemic approach and dynamic modelling.

2. We refer here to the definition provided by Veldkamp and Fresco (1996a) who consider that land use is determined by the interaction in space and time of biophysical factors (constraints) such as soils, climate, topography, etc., and human factors like population, technology, economic conditions, etc. 


\subsubsection{The spatial representation of successive states of a complex system}

The spatialised representation of the land allows us to highlight the successive states of land use and land cover and their past and current changes diachronically. For example, this can be done using schemes - chorems - (Benoit, 1990), GIS (Joliveau, 2004), 3D block diagrams (Michelin, 2000), virtual landscape views (Joliveau and Michelin, 2000; Joliveau, 2001) or even by using remotely sensed data (Hubert-Moy, 2004).

\subsubsection{The systemic approach in geography}

This is a conceptual approach, which may or may not be formalised through a mathematical form, describing several processes and their interactions. The advantage of systemic analysis is that it allows the land to be understood as a dynamic system, which in turn allows us to understand, the mechanisms of the dynamic of human activities in a given geographical space (Chamussy et al., 1986). The systemic approach applied in geography therefore seeks to establish all of the spatiotemporal interactions from among historic, economic, social, mental, physical and natural constraints and a given piece of land. All of these interrelations have an influence on the functioning and the structuring of this land, and even on the functioning and structuring of other encompassing, included and neighbouring territories (Marchand, 1996). The systemic approach forms the conceptual basis for dynamic and spatially explicit models which take into account in the simulation the processes of natural land cover dynamics and possible human land use changes (Dale et al., 1993).

\subsubsection{Spatially explicit dynamic modelling}

Multiple models have been developed to produce simulations of LUCC (Le Ber and Benoît, 1998; Briassoulis, 1999; Agarwal et al., 2000; Veldkamp and Lambin, 2000). A model is dynamic when it integrates the notion of evolution, whether this is over time and/or space. Some of them may be "spatially explicit" that is to say, that these models are distributed in space and are "spatially intelligent". They integrate different levels of spatial interactions (neighbour and/or multi-scalar relationships) to simulate land evolution. Three model types can be distinguished: cellular automata (White and Engelen, 1993; Batty and Xie, 1994; Langlois, 2005), multi-agent systems (Ferber, 1995; Sanders et al., 1997; Poix and Michelin, 2000; Daudé, 2005) and neuronal networks (Paegelow et al., 2004).

\subsubsection{Prospective scenarios / simulations of LUCC}

\subsubsection{Semantic distinction}

Narratives and models are increasingly combined, the latter allowing the trends of certain variables to be quantified (climatic variables, etc.). Through simulations, they allow the model to be explored (Ginot et al., 2006) (sensitivity analysis, 
robustness analysis) or even to experience a set of combinations. A simulation will be a prospective scenario if, and only if, the hypotheses upon which it is based are plausible and coherent with each other, i.e. representative of a possible future situation of a territory.

\subsubsection{Future studies in land cover and use changes}

Here, the objective is not to present an exhaustive list of existing studies, but to provide a summary of the advances in terms of the spatialisation of prospective scenarios, based on examples conducted in different thematic: the study of climate change (Liu et al., 1999, 2003; Kerr et al., 2003), town planning (Goetz et al., 1998; Wang and Zhang, 2001; Jantz et al. , 2003; de Nijs et al., 2004; Veldkamp and Fresco, 1996b), agriculture (Moore et al., 1992; Verburgh et al., 2000; Ewert et al., 2005; Rounsevell et al., 2005; Nassauer and Corry, 2004), rural land abandonment (Piveteau, 1995; Michelin, 2000) and water and/or biodiversity management (Poux et al., 2001; Kersebaum et al., 2003; Baker et al., 2004; Narcy et al., 2006) etc. It appears that: (1) studies that use dynamic models to spatialise and quantify changes LUCC focus on large areas of land (regional or continental scale), (2) there are fewer studies that investigate finer scales, and these are generally in the form of exploratory scenarios relying exclusively on narratives that are sometimes coupled with successive spatial representations.

\section{Building spatialised prospective scenarios at a local scale - methodology and application on water management in Brittany}

The method developed to build spatialised prospective scenarios at a local scale is based on the "scenarios' method", by integrating the spatial dimension throughout the scenario-building process (figure 2). Details of the method are given in the sections below; it has been applied on case study of sustainable water management in Brittany, and more precisely, within the framework of the implementation of the WPMS of the Blavet watershed.

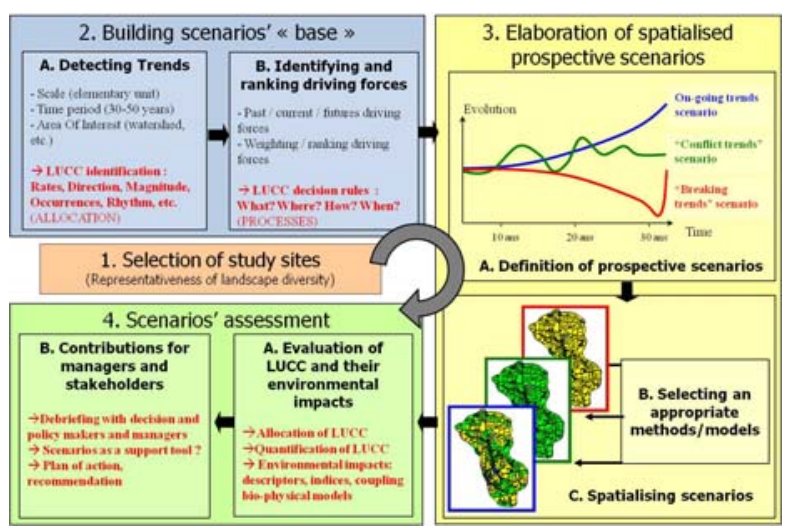


Figure 2. Diagram of the methodological approach for building spatialised

prospective scenarios

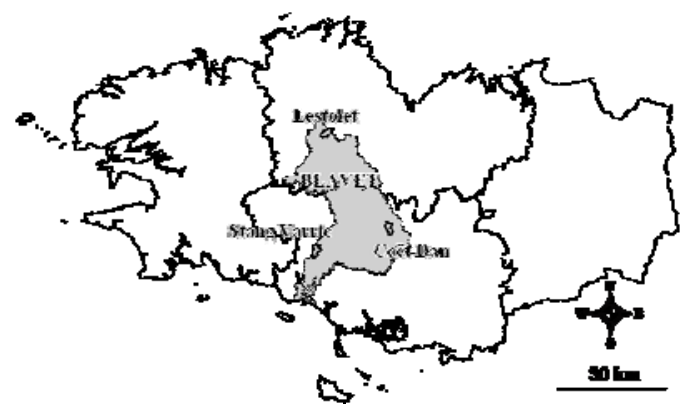

\subsection{Choosing study sites}

The implementation of the WPMS of the Blavet watershed $\left(2000 \mathrm{~km}^{2}\right)$ comprised an application framework specific to these research matters. The objective of producing fine scale spatialised prospective scenarios on small sites (approx. $1400 \mathrm{ha}$ ) was to assess possible future changes focusing on possible impacts of LUCC on water quality issue, to supply more global scenarios (at the entire scale of the Blavet watershed) relating to all water management issues (drinking water supply, management of water flows, navigation, fishing, etc.).

Three small catchment basins were chosen in partnership with the WPMS's Blavet interdepartemental institution - they were Lestolet (Côtes-d'Armor department), Coët-Dan and Stang Varric (Morbihan department) (figure 3). These sites were chosen because they were representative of the landscape diversity (bocage landscape -Burel and Baudry, 2000-, open fields and mixed landscapes), agriculture diversity (dairy production versus confined livestock production, extensive production versus intensive production) and because of contrasted water quality management issues from the north to the south part of the Blavet watershed.

Figure 3. Location of the three study sites: Lestolet, Coët-Dan and Stang Varric

\subsection{Constructing the "base"}

Constructing the "base" involves understanding how a "bocage agricultural land" system works, showing the key variables of current and future changes and identifying the processes that make it evolve. It is based on two successive phases: (1) determining the LUCC trends of the study sites using remotely sensed data and 
reports produced from participative meetings held with a group of local stakeholders and experts; (2) identifying and placing in a hierarchy all of the factors that explain the changes shown using a systemic analysis and a geostatistical study. The methodological approach and the results obtained are developed in detail in Houet et al. (2008).

The main processes and factors of LUCC were identified by analysing the functioning of these agricultural land systems. Farming activities, due to the production, maintenance and land management they involve, are the main factors influencing observed LUCC (Thenail, 1997). The changes occurring at the level of the farms patchwork explain the evolution of the agricultural landscape. Main land changes concern: land structure (recovering of farms, increasing plot sizes), land cover (change of crop proportions linked to a type of production, cultural successions, changes in cultural successions), riparian wetlands located in valley bottoms (changes of land cover due to land abandonment, spatial extension or reduction due to drainage) and hedgerows network (creation and/or levelling of hedgerows) (Houet and Gaucherel, 2007). The evolution of the farming context (market changes, reform of agricultural and environmental policies, etc.) forces farmers to adapt their activities (land management, land practices...), which are also influenced by the decreasing number of farmers. As a result, any factor which affects farming practices plays a part in changing the composition and organisation of the landscape.

\subsection{Producing spatialised prospective scenarios}

Once all of the processes and factors that make the land system evolve have been identified, the prospective scenarios have been built according to the various water management priorities. The method used to spatialise the scenarios depends on the type of scenario adopted.

\subsubsection{Identifying the medium and long-term water management priorities}

The priorities relating to the sustainable management of water resources were determined during a participative meeting bringing together water managers (The water agency, the WMPS Blavet institution, public-private entities and local authorities) and other stakeholders (local elected representatives, farmers and the agriculture councils). Two major priorities were defined: (1) understanding the processes and factors of LUCC and their interactions; (2) delimiting a range of possible futures to contribute towards assessing water management methods. Facing these two priorities, exploratory and normative scenarios are required. To do this, eleven prospective scenarios were produced (Houet, 2006a): eight exploratory scenarios and three normative scenarios. The exploratory scenarios, by simulating the processes of LUCC, allow possible influences of future driving forces or changes of current factors, such as the 2006 common agricultural policy (CAP) 
reform or growing farm sizes and their interactions, to be localised and quantified. The objectives of normative scenarios are to produce plausible situations, based on very contrasting hypotheses of futures hedgerow densities, riparian wetland compositions and land cover proportions to report on the methods that should be used to avoid or achieve one of these situations and to show the relative effectiveness of some water management actions.

To illustrate this methodological approach, an exploratory scenario and a normative scenario are presented here. The first is based on the following assumptions: the 2006 CAP reform will encourage farmers to slightly intensify their production and that the evolutionary trend of the growing size of farms will continue. The temporal horizon for the exploratory scenario should have been limited to 2014, which is the theoretical deadline for applying the 2006 CAP reform. However, this timeframe is too close to the present to be able to show any real changes. Therefore, we issue the hypothesis that the CAP reform will be extended until 2020, because the 2006-2020 period presents similar duration of the 1992 CAP reform (1992-2006), and also because the European Union is not expected to fully redefine this financial assistance system which required five years to be fully defined. The normative scenario presented here is based on three landscape change hypotheses: an accelerating decline in hedgerows density; the almost complete closure of valley-bottom riparian wetlands, which translates into an extension of fallow land and wooded surfaces; a 2006 CAP reform promoting the planting of cereals (maize, wheat) almost everywhere. The year 2027 is the temporal horizon for this scenario: it corresponds to the latest possible application date for the Framework water directive.

These scenarios have been produced on the Lestolet catchment basin where environmental (contamination of water by nitrates) and social (rural depopulation) issues have resulted in all stakeholders becoming heavily involved. The initial year for these two scenarios is 1998, for which exhaustive data on farms were available.

\subsubsection{Choosing an appropriate spatialisation method}

The objective of spatialising prospective scenarios is to precisely represent images of the future in a cartographical form. The selection of a particular spatialisation method depends on the way time is considered in the scenarios.

While it may appear logical to use dynamic models to spatialise exploratory scenarios, there is no method which allows the user to dynamically simulate backward in order to obtain the exact desired spatial configuration, as described in normative scenarios. The only way to provide spatial representation of landscape changes and illustrate its evolution is the diachronic approach.

\subsubsection{The method for spatialising exploratory scenarios}

Studies by Gaucherel et al. (2006) and Houet and Gaucherel (2007), based on a comparative approach of existing simulation models and platforms, have shown that 
the L1 platform was the most suitable for spatialising exploratory scenarios within fragmented agricultural landscapes and more specifically, bocage landscapes. This modelling platform has the advantage to simulate, in a dynamic and spatially explicit way, the geometric and attribute changes of spatially differentiated objects (linear, polygons) and to consider spatial proximity and multiscalar relationships. Its functioning, which is presented in detail in Gaucherel et al. (2006), Houet (2006b) and Houet and Gaucherel (2007), allows changes of land use, land cover and landscape structure to be modelled at different user-defined time steps. In our case, L1 simulates for each year all land uses and factors that make them change based on a script describing their occurrence in time up to the temporal horizon of the scenario. For example, cultural successions are simulated annually for each farm achieving average yearly crop proportions (proportion of meadows, maize and wheat) varying according to production systems and respecting geographical, pedological and agronomic constraints. The script can also foresee in a deterministic manner that for a given date, in 2006 for example, the proportions of land covers of different production systems change traducing the influence of the 2006 CAP reform. Future land cover proportions having been determined by experts. Therefore, all of the processes identified during the construction of the "base" have been modelled, can be defined and modified so as to retranscribe, in the form of successive and combined rules, the previously-built prospective scenario.

The model used has been validated by simulating the evolution of the Lestolet landscape between 1981 and 1998 and by comparing the results obtained with the real situation in 1998 (Houet and Gaucherel, 2007). The real and simulated landscapes present strong similarities in terms of spatial organisation (distribution of cumulated maize surfaces for different classes of distance from hydrographical network; for different field sizes) and in terms of composition (similar proportions of land cover classes). This comparison has also permit to improve some processes, such as cultural successions for specific production systems (Houet, 2006b). Ultimately, the use of randomness for some of these processes (for e.g. ramdom allocation of land cover changes) does not allow to reach exactly the real situation to, but it meets the objectives of the prospective approach by bringing realism and plausibility to the simulated changes.

\subsubsection{Method for spatialising normative scenarios}

The principle of normative scenarios is to build, using contrasting hypotheses, an image upon which the pathway is built backward to the initial image. Therefore, each - synchronic - image is spatially rendered, the dynamic between two images is being produced through the diachronic analysis. Unlike chorems and block diagrams which are unsuitable for producing plausible and realistic images, GIS offer several advantages: (1) they facilitate data exchange with local stakeholders and water managers; (2) the prior construction of the "base" (reconstruction of past LUCC trends) using a GIS considerably facilitates the production of these images, as the layers of geographical information have already been made; (3) future LUCC 


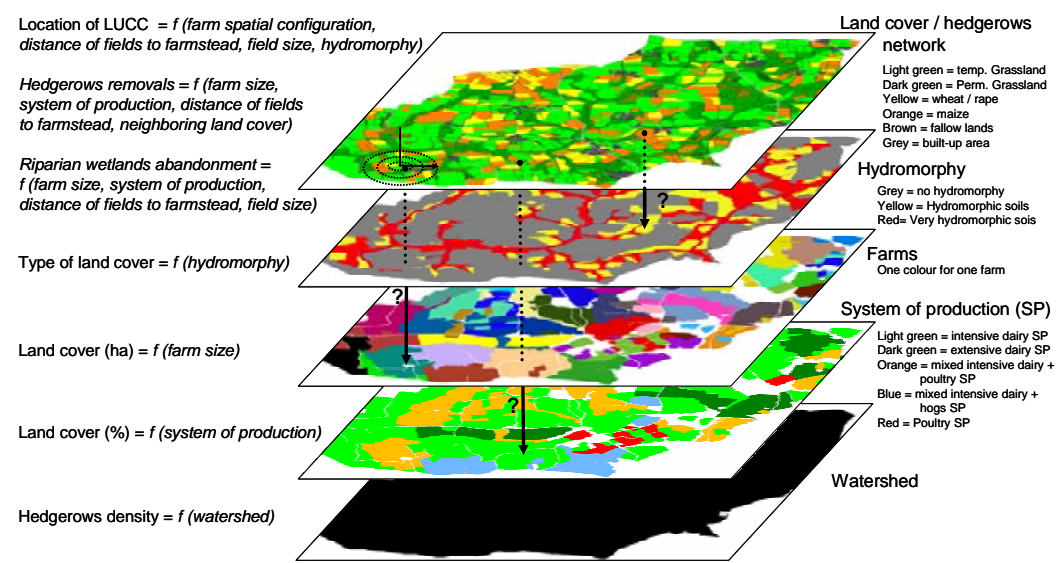

can be quickly localised and represented in a plausible and realistic manner using multi-criteria, attribute and/or spatial queries.

Figure 4 presents the requests which have been used to allocate future LUCC for normative scenarios. For example, a farm that would recover another one which has a different production system would engender LUCC for the fields that have been taken over. Land cover types are then allocated according to the crop proportions of the corresponding production system of the recovering farm, the distance from the new farmstead, the size and the hydromorphy of recovered fields.

The methods presented here for spatialising prospective scenarios relate to very precise landscape objects (fields, hedgerows). Using precise rules, identified during the construction of the "base" (for e.g. no levelling of hedges located between two farms) and random allocation when several possibilities exist in the location of the changes, gives the simulations plausibility and realism which is coherent with the long-term temporal horizon (20-30 years). This also means that several images or land cover maps are possible for each scenario.

Figure 4. Use of a GIS and multi-criteria queries to spatialise a normative prospective scenario

\section{Results}

This part presents two examples of explorative and normative scenarios based on the analysis of the potential impact of the 2006 CAP reform and of the increasing size of farms on LUCC. 


\subsection{The exploratory scenario}

\subsubsection{Narrative: "an adaptation strategy based on cash crops "}

Following the application of the CAP reform in 2006, the uncertainties about new methods for calculating CAP subsidies encouraged farmers to plant slightly more wheat $(+5 \%)$, to ensure that they would receive the subsidies allocated to cash crops (wheat). Based on the existing data on the Lestolet farms in 1998 and 2005 (age of the farmers, agricultural surfaces, conformity to environmental standards, etc.), it was estimated that 17 clearly-identified farmers of the 31 existing farmers in 1998 would get retired by 2020. Of these 17 cessations, 6 farms would be recovered by a new young farmer and the other 11 would be recovered by neighbouring farms. The farm recovering would reflect increasing specialisation in dairy production of the region of upper Blavet, following regional farming trends (Institut de l'élevage, 2004) and the forecasts made by local agricultural stakeholders.

This scenario defined all of the elements that were used to configure the L1 platform. The simulations are carried out from the year 1998 where exhaustive data

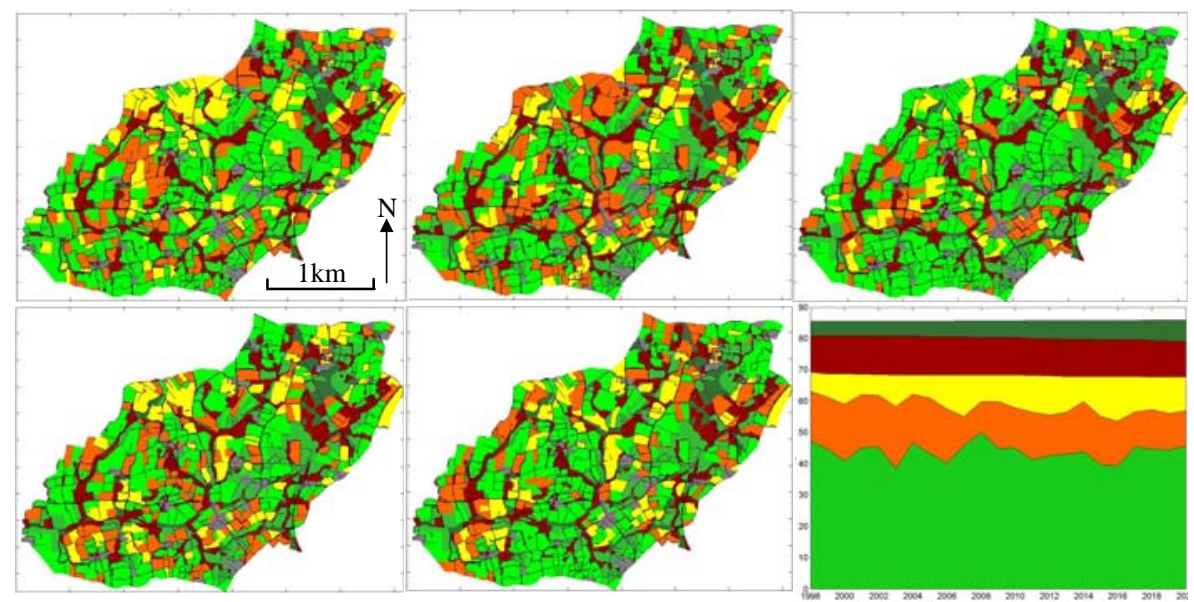

on Lestolet exist, until 2020. The obtained maps and the evolution of the proportions of land cover types at the watershed level are presented in figure 5.

Figure 5. Spatialisation of the exploratory scenario - maps (every 5 years) and annual evolutions of land covers proportions (light green: temporary grassland; medium green: permanent grassland; dark green: Woodland; orange: maize; yellow: wheat; brown: fallow land) 


\subsubsection{Land use and land cover changes}

In this scenario, crops (maize, cereals) shows the same amount of surfaces as in 1998 within the Lestolet catchment basin. There is a slight tendency towards grouping fields of crop land. After 2006, the proportion of cereals increased considerably, from $7.5 \%$ on average before 2006 , to $11.1 \%$ after 2006 , representing an amount of 48 ha. The proportion of cultivated areas has remained stable at $43.9 \%$ before 2006 and $43.7 \%$ after 2006. However, a slight decrease has been observed since 2006: between 2006 and 2013, the cultivated proportion is $44.2 \%$ compared to 43.2\% between 2013 and 2020. Maize accounts for only $13.2 \%$ of the catchment basin area after 2006 compared to $17.2 \%$ before 2006. The closure of riparian wetlands in valley bottoms continues: only 23 ha of permanent grassland remain in 2020, compared to 36 ha in 1998.

Although the changes do not appear to be very striking in comparison with the initial situation, they hide a more complex reality: the CAP reform may encourage intensification of wheat production, bringing about a change in cultural successions, particularly in the frequency of fields being returned to maize cultivation. This could have beneficial environmental consequences on nitrate leaching: the reduction in the occurrence of maize lowers the risk of contamination of surface and subsurface waters.

\subsection{The normative scenario}

\subsubsection{The narrative: "Generalised intensification and minimal management of landscape structures"}

In November 2005, the details of the 2006 CAP reform were finally revealed and farmers discovered the value of the subsidies, which were calculated based on production levels between 2000 and 2002, and which they would receive every year until 2013-2014. The complex Single Payment Scheme (SPS) system encouraged farmers to produce at least the same amount of cereals to retain $100 \%$ of the subsidies allocated to cash crops. In 2006, the price of wheat on the world market continued the downward trend that had been observed previously. The farmers of Lestolet are primarily breeders and everything worked out to not immediately change crop proportions at the production system level. During the same year, the WPMS of Blavet watershed was adopted. Priority was given to the most intensive catchment basins and Lestolet was not one of them. Therefore, farms continued to manage their production as they did before the 2006 CAP, but with a slight increase in wheat (5\%) to the detriment of temporary grassland and maize in order to receive the subsidies for cash crops.

Between 2005 and 2014, some farms increased considerably in size, following the retirement of a third of the farmers in Lestolet. This recovering of the dairy quotas, SPRs (single payment rights) and land led to intensification of the 
production system. Therefore, the proportion of meadows, necessary for pasture and feed, did not evolve proportionally with the milk quotas and slightly decreased at the farm scale relatively to others crops. Only permanent hydromorphic grasslands located near to the farmstead were still used. Individual hedgerow-levelling initiatives continued the same trends as they had over the previous fifty years. Hedgerows surrounding farmsteads and meadows, on the border of farms with different users, as well as the hedgerows surrounding the riparian wetlands of valley bottoms, were not concerned.

From 2010, following the oil crisis of 2006 and 2008, biofuels production which had been marginal before 2008 became a necessity and farmers started to be widely produced. So, after 2010, a significant increase was observed in the production of oilseed and protein crops (biodiesel) and of maize and wheat (bioethanol). Dairy farms thus tended to increase the proportion of crops in their rotation, reducing the pasture area as much as possible in favour of confined dairy production, like what has already been practised in the Netherlands for almost 10 years. In 2014, the 2006 CAP subsidy system is not fundamentally thrown into question and is extended until 2022 thanks to the French presidency of the European Community. Farmers in Lestolet remain sensitive to the environmental issues of their catchment basin and try to have the best possible fertilisation practices, as long as this is profitable for them.

In 2015, under pressure from the international community as a result of American scientific studies, and due to a lack of scientific results from European laboratories and inflationary oil prices, the French state and the European Union authorised the use of genetically-modified crops. The American "Corn Belt" model of the years 2000-2005 was implemented in Brittany and in other regions of France. Within 2 years, a network of food and chemistry industries (based on agricultural products) restructured itself to absorb this production that had been massively adopted by farmers in Brittany. However, wheat production was maintained in order to receive the cash crops subsidies. At the farm scale, meadows were kept to a strict minimum for the pasture of cows to comply with the principle of eco-conditionality (animal welfare).

The two consecutive droughts of 2018 and 2019, even more severe than the ones of 2003 and 2005, finally convinced the last reluctant farmers. GM crops were much more resilient to drought. Farm sizes continued to increase, causing almost complete abandonment of the riparian wetlands in valley bottoms. Only the permanent meadows located near to farmstead have not turned into fallow land. The old fallow lands have almost all turned into woodlands. Farms evolution is translated into an increase in the proportion of maize combined with confined dairy production. It ties in with an attempt to simplify the work of farmers as much as possible. With the continuing growth in farm sizes, hedgerows become a real inconvenience. Across the whole 2015-2027 period, all the hedgerows not located around the farmstead and surrounding meadows, on the border of farms with different users, as well as the hedgerows surrounding riparian wetlands were progressively levelled (figure 6). 


\subsubsection{Land use and land cover changes}

Therefore, in 2014, the Lestolet wateshed has almost 392 ha of temporary grassland, 37 ha of permanent grassland (compared to 41 in 2005), 307 ha of maize and 300 ha of wheat. Hedgerow density has drastically decreased, reaching $96 \mathrm{~m} / \mathrm{ha}$, i.e. $133 \mathrm{~km}$ of hedgerow compared to $170 \mathrm{~km}$ in 2005: $9 \mathrm{~km}$ of wooded linear structures have disappeared in the catchment basins and $28 \mathrm{~km}$ disappeared following the evolution of fields (fallow land or other) into woodland. Riparian wetlands have not declined in terms of area, but they have known a dramatic landscape enclosure (31 ha of permanent grassland, 57 ha of fallow land and 132 ha of woodland, compared to, respectively 40 ha, 123 ha and 57 ha in 1998), causing a likely drop in the biodiversity of flora and fauna. The nitrate concentration, which varies between 40 and $45 \mathrm{mg} . \mathrm{L}^{-1}$ is a result of the increase in the crops proportion in the catchment basin. Moreover, another environmental problem is appearing in the Lestolet study site: the enclosure of the riparian wetland in the bottom of valleys has led to a strong increase in biomass decomposition and, consequently, to eutrophication phenomena. 

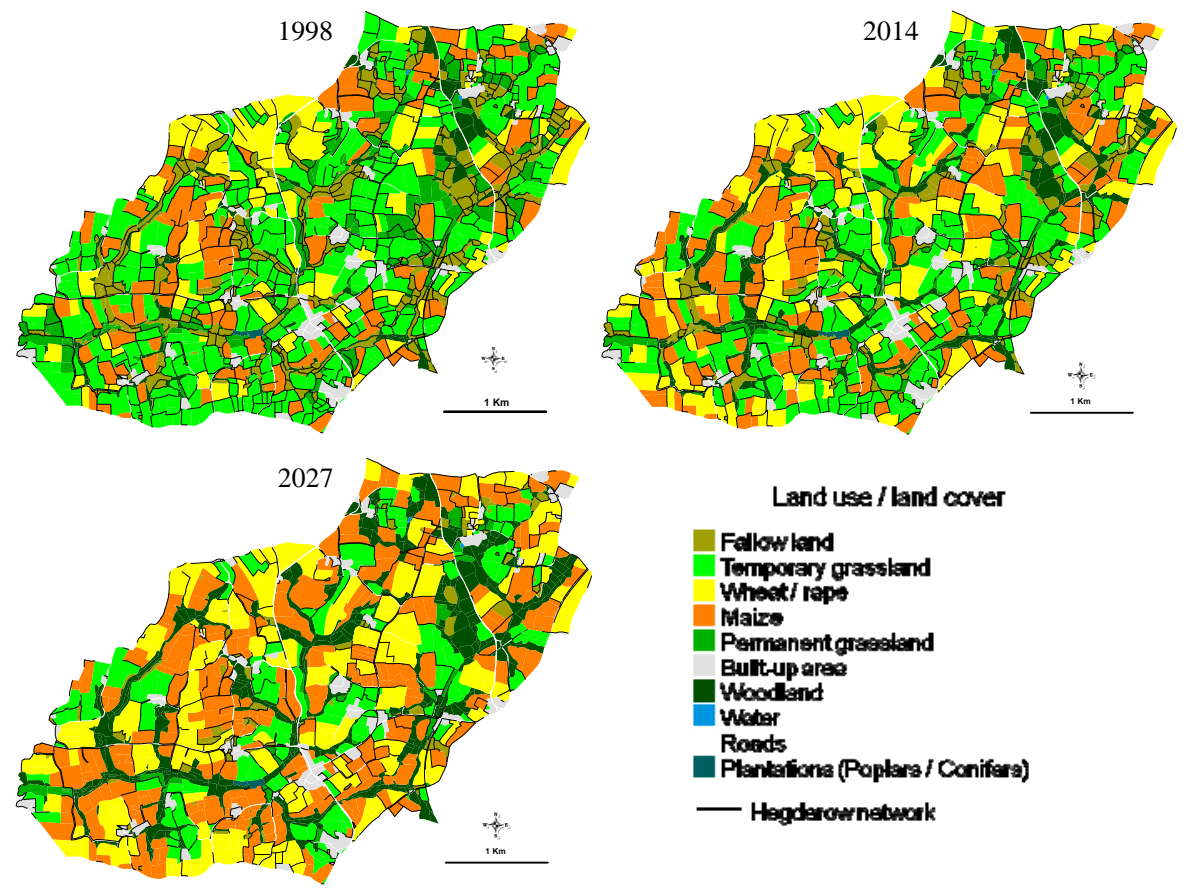

\section{Land use / land cover}

Fellow tend

Temporary grasskand

Whock/ reps

Maizo

Pommanent graseatand

Bult-up arese

Woodand

Water

Roads

Plankationa (Poplars/ Conifera)

Hegderowneturatk

Figure 6. Spatialisation of the normative scenario: initial image in 1998, intermediary image in 2014 and final image in 2027

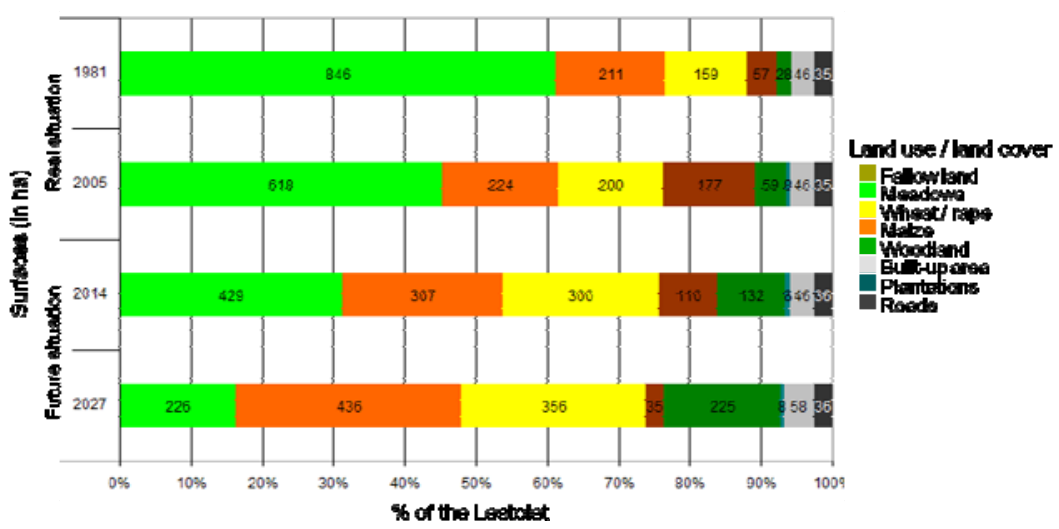

Figure 7. Evolution of LUCC proportions according to the real situation and the normative scenario over the 1981-2027 period 
In 2027, the majority of the arable land in Lestolet was converted into crops (436 ha of maize, 356 ha of wheat/oilseed and protein crops). Meadows survive only near to farms (204 ha of temporary grassland, 22 ha of permanent grassland). The density of the hedgerows has fallen dramatically between 2014 and 2027, ultimately reaching $64 \mathrm{~m} / \mathrm{ha}$, i.e. a loss of $82 \mathrm{~km}$ of hedgerow within 15 years. This loss is a result of the levelling of $27 \mathrm{~km}$ of hedges on the catchment basins and the evolution of fields (fallow land or others) into woodlands (non-differentiation of the $55 \mathrm{~km}$ of surrounding hedgerows). The riparian wetlands are almost all enclosed. Only 22 ha of permanent hydromorphic meadows remain, compared to 190 ha of wood and 8 ha of damp wasteland. Therefore, the nitrogen concentration regularly exceeds $50 \mathrm{mg} . \mathrm{L}^{-1}$; the phosphorous concentrations are alarming and lead to increasingly frequent eutrophication.

This scenario which will be realised if the current trends continue (1981-2005) represents an evolution which has dramatic environmental consequences (figure 7). This evolution is the result of a very restrictive international economic context (oil market, agricultural markets), the policy environment towards GMOs destined for new markets (biofuels) and the lack of concerted effort between farmers and water managers.

\subsection{Assessment and contribution of spatialised prospective scenarios}

In prospective, it is impossible to know whether what is described in the scenarios will take place or not, as prediction is not the objective that is being pursued. However, the prospective can be the subject of several kinds of assessment. It can be assessed: (1) a posteriori, using an approach called the retro prospective approach, the actual situation thus being compared with the situation(s) envisaged by the scenarios; (2) via the assessment of the functioning of the methods used to build scenarios (models, probabilities, etc.), by checking the relevance, coherence, plausibility and transparency of the scenarios produced by these methods (Houet and Gaucherel, 2007); (3) by measuring the impact of future changes on the environment (impacts on water quality, biodiversity etc.) and on society (social and economic costs, etc.); (4) via the contribution that it produces to stakeholders and decision-makers (Piveteau, 1995).

All of the eleven scenarios produced on the three study sites have been assessed (Houet, 2006a): at the environmental level using a certain number of indicators such as the occurrences of maize per field, cumulated areas of maize classified by distance from the hydrological network (Ruiz et al., 2004) and by coupling future maps with spatially explicit water flow models: Ruicells (Langlois and Delahaye, 2002; Landbuf (Viaud, 2004); Odissés (Bocher and Bedel, 2004); at the human level, by presenting the results in a meeting regrouping water managers and local stakeholders, where an assessment questionnaire on the form and substance of the scenarios has been completed. Although the sample of persons questioned was not 
statistically significant, as the number of participants was limited to 5, it was representative of the diversity of the stakeholders concerned with water management. The conclusions drawn from this assessment can be considered as indicative. In general, the exploratory scenarios have been judged to be from potentially useful to very useful. Major questions on the influence of the 2006 CAP reform and growing farm sizes have probably played a major role in this. Water managers have shown the most interest in these results. Agricultural stakeholders seemed less surprised: some of them had already sensed the influence of growing farm sizes on LUCC, others think that the ensemble of mechanisms are more complex than the ones reproduced by the scenarios and that other factors, such as the allocation of a "function" to some fields ("cultivation", ecological etc.), could have a major influence on the spatial allocation of crops. Nevertheless, they have shown in their assessment their awareness and interest towards the concerns of water management stakeholders.

In the same way, normative scenarios have been judged useful for understanding different points of view (agricultural stakeholders and water managers), but particularly very useful for highlighting the importance of interactions between stakeholders for the sustainable water management. This shows first of all that the narratives, although they are not very synthetic, are an explicit means of demonstrating the weight of stakeholder activities and, consequently, the water management priorities as well as the means required for to act upon them. Most of those that deemed these scenarios as very useful to understand the future were agricultural stakeholders. The hypothesis is that these scenarios bring them an overall vision which is not limited to their operational activity (farm scale).

Finally, the stakeholders all stated that spatial rendering helped them in the sustainable management of water, as the spatialised scenarios brought more realism from a visual and quantitative point of view and thus raised the awareness of all stakeholders concerned. Furthermore, they provide the possibility of producing risk descriptors which can identify areas in which planning or awareness-raising operations can be performed (Houet, 2006b). This assessment has highlighted an essential point in the purpose of prospective scenarios: the opportunity to define future ways of managing water in a concerted manner. This is how the discussion between the stakeholders on spatialised prospective scenarios and their consequences highlighted the importance of integrating land management organism (city council, SAFER (rural land management organism), etc.) in water management. 


\section{Discussion}

\subsection{Contribution of the spatial dimension to prospective scenarios}

Spatialised prospective scenarios, whether exploratory or normative, permit to quantify the possible evolutions of patchy -bocage- landscape, identify the spatial dynamics of future changes and areas at risk for water resources. The function of the spatial dimension differs depending on the type of scenario used. In the case of an exploratory scenario, it primarily emphasises the complexity of LUCC throughout a dynamically and spatially explicit simulation of processes influencing landscape evolution. Furthermore, it can distinguish the respective influences and interactions among the driving factors that had been identified as essential to explore the future of such landscape. In the case of a normative scenario, it improves realism of very contrasted scenarios, which are sometimes considered as unlikely by local stakeholders when reading the narratives. It gives a more realistic context to future evolutions which remain plausible and facilitates awareness-raising of the issues of water management. The spatial dimension facilitates cooperation and participation between all involved stakeholders.

Furthermore, some authors identify changes in land use as a determining factor in the dynamic of anthroposystems and ecosystems (Walker and Will, 1996). This observation poses the problem of selecting a spatial reference unit which acts as an interface between the use and management of rural land and the "natural" evolution processes of the landscapes. The modelling of these processes at a fine scale (field, hedgerows) based on spatialised scenarios therefore presupposes that the system under study and developed is able to integrate the hierarchical theory of space (Burel and Baudry, 1999). Here, GIS technologies (remote sensing and GIS) turn out to be particularly suitable for spatially describing the "agricultural patchy landscape" system, by combining multi-scale and multi-criteria data and by formulating spatialised scenarios. The spatial dimension no longer appears as merely a media to illustrate evolution narratives, but rather as a real pillar in the spatialised prospective approach, from the construction of the "base" (reconstructing LUCC trends, identifying driving forces and LUCC processes, etc.) to producing images of the future in cartographical form (use of spatially explicit simulation models, GIS and multi-criteria requests etc).

Finally, the respective issues of the stakeholders involved in water management (farmers, water agencies, etc.) come under different scales - this is probably the reason for the current lack of efficiency, and even detrimental conflicts. The assessment phase of the approach highlights that both exploratory and normative spatialised prospective scenarios have contributed essential knowledge to them whereas only one of these scenarios wouldn't. It brings a better understanding for water managers of the processes that lead to agricultural patchy landscapes changes and a stronger awareness of global issues which go beyond strictly local - farm scale - issues of farmers. 


\subsection{The fine scale spatialised prospective approach: a tool for supporting and assisting sustainable water management}

Originally, water managers have appeared to lack the tools to implement a sustainable management plan over the medium term (15-20 years). Their objectives were to be as effective as possible, to avoid conflicts with agricultural stakeholders and also to assess possible evolutions of land uses and the potential management options. Plausible and realistic projections have put stakeholders in situation and introduced a relative (temporal) distance to the real situation. Therefore, in accordance with companion modelling principles (Antona et al., 2005), the chosen approach favoured the participation of all by improving knowledge of the processes and increasing stakeholder awareness. The participative approach is one of the basements of the prospective approach. This is done through three participative meetings bringing together local stakeholders and experts. The first sought to identify factors that explain observed LUCC while building the "base". The second was to validate "the base" and to clearly identify the issues and stakes of the prospective scenarios, i.e. to identify what we are trying to show and to answer using them. Therefore, the scenarios produced have been defined by the stakeholders' need to understand: (1) the possible influence of certain key factors on LUCC and (2) the means that should be implemented to achieve or avoid a future situation. The third allowed the prospective scenarios to be presented to involved stakeholders, and then discussed and assessed.

Furthermore, locating potential areas at risk over the medium to long term, such as, for example, a hedgerow which has a major role in water flows and which is at risk of being levelled or fields that show a high occurrence of maize, is already in itself a tool which helps water management. Assessing the impacts of the scenarios on water resources has identified the action that should be taken to ensure more sustainable and effective water management. Some of these actions, such as rationalised fertilisation, covering bare soils in winter, the restoration of hedgerows surrounding riparian wetlands, or even the maintenance of the riparian wetlands in valley bottoms, were already known, but their advantages for stakeholders are consolidated, even reinforced. However, other management solutions have been revealed as a result of this exercise: participation in the management or control of the evolution of farmland structures, local synergies to be implemented and perpetuated between water managers and local stakeholders in the economic and environmental interest of everyone.

\subsection{The spatialised prospective approach: the limits}

There is, we believe, an intrinsic relationship between the spatial and temporal dimensions used during spatialised prospective modelling. In order to be plausible, consistent and realistic, the production of fine scale spatialised prospective scenarios requires a temporal horizon that is not too distant. The uncertainties linked to future 
driving forces (such as the 2013 CAP reform for example) and the precision necessary to produce spatialised prospective scenarios on a local scale for sustainable water management (at the hedgerow and field levels) do not, a priori, allow a distant future to be explored (maximum of around 20-30 years). Finally, the acquisition of the data necessary for modelling relating to farms (farm land use limits, age of the farmers, production system, etc.) places a major limitation on the building of scenarios relating to larger scopes. Finally, if this protocol appears to be relatively consistent to implement, this is because it relates to an investigation matter which it has been necessary to explore and which still remains open for other issues, other type of territories (urban, mountains...). However, with the exception of the exploratory scenarios, the methods required to produce normative scenarios remain easy to broach.

\section{Conclusion}

The main objective of this research was to produce a generic methodological approach in order to produce fine scale spatialised prospective scenarios. Based on the prospective scenarios' method, this approach is improved using methodological contributions used to model complex systems in geography, bringing a spatial dimension to the scenarios. It has four phases. The first phase aims to build "the base" of the scenarios. The second is to produce relevant prospective scenarios to clarify the possible futures of the studied land system. The third is the phase of spatialising the scenarios. The methods differ according to the type of scenarios. In the case outlined here, a dynamic and spatially explicit modelling platform (L1) was used and optimised for exploratory scenarios, while a GIS was used to produce the normative scenarios. Finally, the last phase was to assess the spatialised prospective scenarios, their environmental impacts and their contributions for managers and local stakeholders.

The context of water management in Brittany, and particularly the implementation of the WMPS in the Blavet watershed, was a particularly suitable application framework for this prospective approach. This experiment has shown that the location of areas at risk for water quality resources, as well as the identification of action strategies (local synergies, land management) on sites representative of the diversity of agricultural and landscape situations, give prospective spatialised scenarios a role as a decision support tool for water managers and local stakeholders.

\section{References}

Agarwal C., Green G. L., Grove M., Evans T., Schweik C., A review and assessment of landuse change models: Dynamics of space, time and human choice, General Technical 
Report NE-297, U.S. Department of Agriculture, Forest Service, Northeastern Research Station, 2000.

Alcamo J., Leemans R., Kreileman E., Global Change Scenarios of the $21^{\text {th }}$ Century, Results from the IMAGE 2.1 Model, Pergamon, Elsevier Sciences, 1998.

Antona M., D’Aquino P., Aubert S., Barreteau O., Boissau S., Bousquet F., Daré W., Etienne M., Le Page C., Mathevet R., Trébuil G., Weber J., "La modélisation comme outil d'accompagnement", Natures Sciences Sociétés, vol. 13, 2005, p. 165-168

Baker J. P., Hulse D. W., Gregory S. V., White D., Van Stickle J., Berger P. A., Dole D., Schumaker N. A., "Alternative futures for the Willamette river basin”, Ecological Application, vol. 14, $\mathrm{n}^{\circ}$ 2, Oregon, 2004, p. 313-324.

Batty M., Xie Y., “From cells to cities”, Environment Planning B, vol. 21, 1994, p. 31-48.

Baudry J., Burel F., Aviron S., Martin M., Ouin A., Pain G., Thenail C., "Temporal variability of connectivity in agricultural landscape: do farming activities help?”, Landscape Ecology, vol. 18, n 3, 2003, p. 303-314.

Baudry J., Thenail C., "Interaction between farming systems, riparian zones, and landscape patterns: a case study in western France”, Landscape and urban planning, vol. 67, 2004, p. 121-129.

Benoît M., "La gestion territoire de l'activité agricole dans un village lorrain", Mappemonde, $n^{\circ}$ 4, 1990, p. 15-17.

Bocher E., Bedel O., Odissés 1.0: Outils distribués pour la spatialisation des écoulements superficiels, Didacticiel, Laboratoire RESO UMR 6590 CNRS, 2004, http://r1.bocher.free.fr/index.php?n=Main.Logiciels

Briassoulis H., Analysis of land-use change: Theoretical and modelling approaches, The web book of regional Science, Regional Research Institute, West Virginia University, 1999, http://www.rri.wvu.edu/WebBook/Briassoulis/Chapter2(Histoverview).htm

Burel F., Baudry J., Ecologie du paysage. Concept, méthodes et applications. Lavoisier, Paris, 1999.

Burel F., Baudry J., Thenail C., Le Coeur D., "Relationships between farming systems and ecological patterns along a gradient of bocage landscapes”, in Consequences of land use changes, Ed. Mander Ü. and Jongman R.G.H., WIT press, 2000, p. 227-246.

Caubel V., Influence de la haie de ceinture de fond de vallées sur les transferts d'eau et de nitrate, Doctoral thesis, Ecole nationale supérieure d'agronomie, 2001.

Chamussy H., Le Berre M., Uvietta P., Durand M.G., "Cheminements systémiques du modèle AMORAL à une réflexion théorique en géographie", Grenoble, L.A.M.A., Université de Grenoble, and article in Analyse de système en géographie, (1984), texts compiled by GUERMOND Y., Lyon, Presses Universitaires de Lyon (Systems science collection), 1986.

Cheverry C., Agriculture intensive et qualité des eaux, INRA Editions, 1998.

Clément J.-C., Les zones humides de fonds de vallées et la régulation des pollutions azotées diffuses, Doctoral thesis, Université de Rennes 1, 2001. 
Dale V. H., O’Neill R. V., Pedlowski M., Southworth F., "Causes and effects of land-use change in Central Rhondonia”, Brazil, Photogrammetric Engineering and Remote Sensing, vol. 59, n 6, 1993, p. 997-1005.

Daudé E., "Systèmes multi-agents pour la simulation en géographie : vers une géographie artificielle", in Modélisations en géographie : déterminismes et complexités, Ed. Guermond Y., Hermès Science-Lavoisier, 2005, p. 353-380.

De Nijs T. C. N., De Niet R., Crommentuijn L., "Constructing land use maps of the Netherlands”, in 2030, Journal of Environmental Management, vol. 72, 2004, p. 35-42.

Engelen G., White R., De Nijs A.C.M., "Environment Explorer: Spatial support system for the integrated assessment of socio-economic and environmental policies in the Netherlands", $1^{\text {st }}$ Biennial Conference of the International Environmental Modelling and Software Society, Lugano, 2002, p. 109-114.

Ewert F., Rounsevell M. D. A., Reginster I., Metzger M. J., Leemans R., "Future scenarios of European agricultural land use: I. Estimating changes in crop productivity”, Agriculture, Ecosystems and Environment, vol. 107, 2005, p. 101-116.

Ferber J., Les systèmes multi-agents : vers une intelligence collective, InterEditions, 1995.

Flaxman M., Hulse D.W., Freemark K., Bernert J., Eilers J., White D., Radosevich S., "Past, Present and Future Stresses on the Ecological Resources of the Mid-Willamette River Basin (Oregon)", $11^{\text {th }}$ Annual U.S. Landscape Ecology Symposium, International Association of Landscape Ecology, Galveston, Texas, USA, 1996, http://ise.uoregon.edu/Muddy/MuddyFramework.html

Gaucherel C., Giboire N., Viaud V., Houet T., Baudry J., Burel F., “A domain specific language for patchy landscape modelling: the Brittany agricultural mosaic as a case study”, Ecological Modelling, vol. 194, n 1-3, 2006, p. 233-243.

Ginot V., Gaba S., Beaudouin R., Aries F., Monod H., “Combined use of local and ANOVAbased global sensitivity analyses for the investigation of a stochastic dynamic model: Application to the case study of an individual-based model of a fish population”, Ecological Modelling, vol. 193, n 3-4, 2006, p. 479-491.

Godet M., Crise de la prévision, essor de la prospective, Presses Universitaires de France, 1977.

Godet M., De l'anticipation à l'action, Dunod, 1992.

Goetz S. J., Smith A. J., Jantz C., Wright R. K., Prince S. D., "Monitoring and predicting urban land use change: Applications of multi-resolution multi-temporal satellite data”, IEEE International Geoscience And Remote Sensing Symposium, July 2003, Toulouse, 2003, p. 1567-1569.

Greeuw, S. C. H., van Asselt, M. B. A., Grosskurth, J., Storms, C. A. M. H., Rijkens-Klomp, N., Rothman, D. S., Rotmans, J., Cloudy crystal balls: an assessment of recent European and global scenario studies and models, European Environment Agency, Copenhagen, Denmark, 2000.

Hatem F., La prospective : Pratiques et méthodes, Economica, "Gestion" series, 1993. 
Houet T., Occupation des sols et gestion de l'eau : modélisation prospective en paysage agricole fragmenté (application au SAGE du Blavet), Thèse de doctorat, Université Rennes 2, 2006a.

Houet T., "Modélisation prospective de l'occupation des sols en zone agricole intensive de la France de l'Ouest", Norois, nº 198, 2006b, p. 35-47.

Houet T. and Gaucherel C., "Simulation dynamique et spatialement explicite d'un paysage agricole bocager : Validation sur un petit bassin versant breton sur la période 19811998", Revue internationale de géomatique, vol. 17, n 3-4, 2007, p. 489-520.

Houet T., Hubert-Moy L., Corgne S., Marchand J. P., "Approche systémique du fonctionnement d'un paysage agricole bocager", L'espace géographique, vol. 3, 2008, p. 270-286.

Hubert-Moy L., Occupation du sol et télédétection : de l'inventaire à la modélisation prédictive, Habilitation à diriger des recherches, Université de Rennes 2, Haute-Bretagne, 2004.

Institut de l'élevage, Réforme de la PAC et production laitière : scénarios d'évolution à l'horizon 2010-2012, Le Dossier économie de l'élevage, 2004.

Jantz C., Goetz S. J., Smith A. J., Shelly M., "Using the SLEUTH urban growth model to simulate the impacts of future policy scenarios on land use in the Baltimore-Washington metropolitan area”, Environment Planning B, vol. 30, 2003, p. 251-271.

Joliveau T., "Informatique et paysage", Support de formation - ENGREF, CRENAM / UMR CNRS 5600 - Université de Saint-Etienne, 2001, http://dossier.univ-st-etienne.fr/crenam/www/formationpaysage/index.html

Joliveau T., Géomatique et gestion environnementale du territoire. Recherches sur un usage géographique des SIG, Habilitation à diriger des recherches, Université de Rouen, 2004.

Joliveau T., Michelin Y., Paysages et modèles spatiaux pour la prospective concertée d'un territoire rural, in Représentations spatiales et développement territorial, Ed. Lardon S., Maurel P. et Piveteau V., Hermès, 2001, p. 240-266.

Kerr S., Liu S., Pfaff A. S. P., Hughes R. F., "Carbon dynamics and land use choices: building a regional scale multidisciplinary model”, Journal of Environmental Management, vol. 69, 2003, p. 25-37.

Kersebaum K.C., Steidl J., Bauer O., Piorr H.-P., "Modelling scenarios to assess the effects of different agricultural management and land-use options to reduce diffuse nitrogen pollution into the river Elbe”, Physics and chemistry of the Earth, vol. 28, 2003, p. 537-545.

Julien P.-A., Lamonde P., Latouche D., La méthode des scénarios : une réflexion sur la démarche et la théorie de la prospective, série "Travaux et recherches de prospective", DATAR, La documentation française, Paris, 1975.

Lambin E. F., Baulies X., Bockstael N., Fischer G., Krug T. et al., Land-use and land-cover change (LUCC): Implementation strategy, IGBP Rep. 48, IHDP Rep. 10, Int. Geosph.Biosph. Program., Int. Hum. Dimens. Glob. Environ. Change Program., Stockholm/Bonn, 1999. 
Langlois P., "Les automates cellulaires pour la modélisation de systèmes spatiaux", in Modélisations en géographie : déterminismes et complexités, Ed. Guermond Y., Hermès Science-Lavoisier, 2005, p. 321-352.

Langlois P., Delahaye D., RuiCells, "Automate cellulaire pour la simulation du ruissellement de surface", Revue internationale de géomatique, vol. 12, n 4, 2002, p. 461-487.

Le Ber F., Benoît M., "Modelling the spatial organisation of land use in a farming territory. Example of a village in the Plateau Lorrain”, Agronomie: Agriculture and Environment, $\mathrm{n}^{\circ}$ 18, 1998, p. 101-113.

Liu S., Loveland T. R., Kurtz R. M., "Contemporary carbon dynamics in terrestrial ecosystem in the southeastern plains of the United States", Environmental Management, vol. 33, 2003, p. 442-456.

Liu S., Reiners W. A., Keller M., Schimel D. S., "Model simulation of changes in N2O and NO emissions with conversion of tropical rain forests to pastures in the Costa Rican Atlantic zone”, Global biogeochemical Cycles, vol. 13, 1999, p. 663-677.

Marchand J.-P., "Les contraintes naturelles et l'organisation de l'espace" in Géopoint 96 Espace et nature dans la géographie aujourd'hui ?, Gpe Dupont, Avignon, 1996, p. 9-15.

Mérot P., "The influence of hedgerow systems on the hydrology of agricultural catchments in temperate climate”, Agronomie, vol. 19, 1999, p. 655-669.

Michelin Y., "Le bloc-diagramme: une clé de compréhension des représentations du paysage chez les agriculteurs? Mise au point d'une méthode d'enquête préalable à une gestion concertée du paysage en Artense (Massif central français)", Cybergéo, n 118, 2000.

Moore D. G., Tappan G., Howard M. S., Lietzow R. W., Nadeau C. A., Renison W., Olsson J., Kite R., Geographic modeling of human carrying capacity from rainfed agriculture: Senegal case study, Technical report, US Agency for International Development, Washington, 1992.

Morin E., Introduction à la pensée complexe, E. S. F éditeur, 1990.

Muchoney D., Geographic Analysis and Monitoring Program - 5-year program plan, United States Geological Survey, 2002.

Narcy J.-B., Poux X., Houet T., "Méthode et apports d'une intervention prospective dans une problématique de gestion des eaux: le cas du Blavet", in Qualité de l'eau en milieu rural : savoirs et pratiques dans les bassins versants, Ed. P. Mérot, Editions Cemagref, Cirad, Ifremer, Inra, 2006, p. 287-296.

Nassauer J. I., Corry R. C., "Using normative scenarios in landscape ecology”, Landscape ecology, vol. 19, 2004, p. 343-356.

Paegelow M., Villa N., Cornez L., "Modélisations prospectives de l'occupation du sol. Le cas d'une montagne méditerranéenne", Cybergéo, n² 295, 2004, p. 1-19.

Piveteau V., Prospective et territoires: apports d'une réflexion sur le jeu, Collection Etudes, Série Gestion des territoires, Cemagref Editions, Antony, 1995.

Poix C., Michelin Y., "Simulation paysagère : un modèle multi-agent pour prendre en compte les relations sociales", Cybergéo, ${ }^{\circ} 116,2000$, p. 1-10. 
Poux X., "Les méthodes des scénarios", in Prospectives pour l'environnement : Quelles recherches ? Quelles ressources ? Quelles méthodes ?, Ed. Mermet L., La documentation française, 2003, p. 33-50.

Poux X., Mermet L., Bouni C., Narcy J.-B., Dubien I., Méthodologie de prospective des zones humides à l'échelle micro-régionale - problématique de mise en œuvre et d’agrégation des résultats, Rapport scientifique au PNRZH, AScA, 2001.

Rounsevell M. D. A., Ewert F., Reginster I., Leemans R., Carter T. R., "Future scenarios of European agricultural land use: II. Projecting changes in cropland and grassland", Agriculture, Ecosystems and Environment, vol. 107, 2005, p. 117-135.

Ruiz L., Aurousseau P., Baudry J., Beaujouan V., Cellier P., Curmi P., Durand P., GascuelOdoux C., Leterme P., Peyraud J.-L., Thenail C., Walter C., "Conception de bassins versants virtuels : vers un outil pour l'étude de l'influence de l'organisation spatiale de l'activité agricole et du milieu physique sur les flux d'azote dans les bassins versants", in Organisation spatiale des activités agricoles et processus environnementaux, Ed. Monestier P., Lardon S. and Seguin B., INRA Editions, 2004.

Sanders L., Pumain D., Mathian H., Guerin-Pace F., Bura S., "SIMPOP : a multiagent system for the study of urbanism”, Environment Planning B, vol. 24, 1997, p. 287-305.

Steinitz C., Rojo H. M. A., Basset S., Flaxman M., Goode T., Maddock T., Mouat D., Peiser R., Shearer A., Alternative Futures for Changing Landscapes : The Upper San Pedro River Basin in Arizona and Sonora, Island Press, Washington, D. C., 2003.

Thenail C., Exploitations agricoles et territoires : contribution à la structuration de la mosaïque paysagère, Doctoral thesis, Université de Rennes 1, 1996.

Thenail C., "Le rôle des exploitations agricoles dans l'évolution des paysages : un facteur essentiel des dynamiques écologiques", Ecologia Mediterranea, vol. 23, 1997, p. 71-90.

Turner B. L., Skole D., Sanderson S., Fischer G., Fresco L. O., Leemans R., LUCC Science Research Plan, IGBP Rep. 35, HDP Rep. 7, Int. Geosph.-Biosph. Program., Int. Hum. Dimens. Glob. Environ. Change Program, Stockholm/Geneva, 1995, http://www.icc.es/lucc/sciencep/scienceplan.htm

UNEP, One planet, Many people - Atlas of our changing environment, Division of Earth Warning and Management, United Nation Environment Programme, UNEP/Earthprint, Nairobi, Kenya, 2005.

Veldkamp A., Fresco L. O., "CLUE: a conceptual model to study the Conversion of Land Use and its Effects”, Ecological Modelling, vol. 85, 1996a, p. 253-270.

Veldkamp A., Fresco L. O., "CLUE-CR: an integrated multi-scale model to simulate land use change scenarios in Costa Rica”, Ecological Modelling, vol. 91, 1996b, p. 231-248.

Veldkamp A., Lambin E. F., "Predicting Land-use change”, Agriculture, Ecosystems and Environment, vol. 85, $\mathrm{n}^{\circ} 1-3,2001$, p. 1-6.

Verburg P. H., Chen Y. Q., Veldkamp A., "Spatial explorations of land use change and grain production in China”, Agriculture, Ecosystems and Environment, vol. 82, 2000, p. 333-354.

Viaud V., Organisation spatiale des paysages bocagers et flux d'eau et de nutriments, Doctoral thesis, Ecole nationale supérieure d'agronomie de Rennes, 2004. 
Fine scale spatialised prospective modelling

Walker B., Will S., Global change and terrestrial ecosystems. Cambridge University Press, 1996.

Wang Y., Zang X., "A dynamic modeling approach to simulating socioeconomic effects on landscape changes”, Ecological Modelling, vol. 140, 2001, p. 141-162.

White R., Engelen G., "Cellular automata and fractal urban form: a cellular modelling approach to the evolution of urban land use patterns”, Environment Planning A, vol. 25, 1993, p. 1175-1199. 